\title{
The Hermeneutics of Scribal Rewriting in Targum Jonathan Ezek 1
}

\author{
William A. Tooman (University of St. Andrews)
}

\begin{abstract}
This paper examines a number of expansions and rewordings in $\mathrm{Tg}$. J. Ezek 1 that alter or elaborate upon the description of the celestial creatures. The object is threefold: to identify textual cues within the Targum's Vorlage that sparked expansions or rewordings, to explain the exegetical choices reflected in those expansions and rewordings, and to deduce something about the hermeneutical assumptions under which those choices were made. Along the way, I explain several features of the Targum in new ways, but the principal objects of my inquiry are the scribes responsible for Targum Jonathan and the various ways that they interacted with their Hebrew Vorlage. I propose that the expansions and rewordings never reflect exuberance or whimsy on the part of the targumic scribes. Rather, they represent a disciplined effort to produce an accurate reading of their Hebrew text, undertaken according to certain hermeneutical assumptions, assumptions that are co-extensive with their assumptions about the nature of their source texts as scripture.
\end{abstract}

This paper examines a number of expansions and rewordings in Targum Jonathan (Tg. J.) to the first chapter of the biblical book of Ezekiel, which alter or elaborate upon the description of the celestial creatures (Heb hayyôt; Aram biryān). The object is not, primarily, to expound its ideas nor to correlate them with other traditions in early Jewish thought. Instead, my aim is threefold: to identify textual cues within the Targum's Vorlage that sparked expansions or rewordings, to explain the exegetical choices reflected in those expansions and rewordings, and to deduce something about the hermeneutical assumptions under which those choices were made. Along the way, I explain several features of the Targum in new ways, but the principal objects of my inquiry are the scribes responsible for Targum Jonathan and the various ways that they interacted with their Hebrew Vorlage. I will propose that the expansions and rewordings never reflect the exuberance or whimsy of the targumic scribes. Rather, they represent a disciplined effort to produce an accurate reading of their Hebrew Vorlage undertaken according to certain assumptions about the nature of their source text as scripture.

Several remarks are required before I begin. First, the compound "expansions and rewordings" necessitates clarification. Expansions are a commonplace of text-criticism and translation theory, and I use this term in a typical way: to refer to elements of the Aramaic version that have no equivalent in

1 I have attempted this in another context. See W. A. Tooman, "To Do the Will of their Master: Re-envisioning the Hayyôt in Targum Jonathan of Ezekiel," in "I Lifted My Eyes and Saw": Reading Dream and Vision Reports in the Hebrew Bible (eds. E. R. Hayes and L.S. Tiemeyer; Edinburgh and London: T \& T Clark, 2014), 221-33. 
its Hebrew Vorlage. "Rewording," however, is a less obvious term. By this I indicate instances wherein a Hebrew word is rendered with something other than its most obvious cognate or common Aramaic equivalent. (An example of this phenomenon is available in n. 4, below.) Second, I do not use "scribe" in the traditional sense, to indicate a "copyist." I use "scribe" to indicate one who both transmits written material and adapts it: arranging, expanding, contracting, and conflating. ${ }^{2}$ Third, the attempt to focus attention on scribal mechanics, the actual phenomena of expanding and rewriting, in isolation from the wider conceptual and doctrinal issues at stake in early Judaism is, admittedly, somewhat artificial. I do this to isolate and underline the ways that acts of writing and rewriting can illuminate our understanding of the scribes' attitudes toward their source texts, casting direct light on the functional dimension of scripture within the targumic enterprise. ${ }^{3}$ Finally, although the principal focus of this essay is on the scribes who produced Targum Jonathan, the particular pericope in view, Ezek 1, was selected because it is part of Ezekiel's merkabâa vision that has, as one of its central foci, the hayyôt, the celestial hybrid-beings. ${ }^{4}$ The biblical roots of merkabâ mysticism and early Jewish angelology are points of particular interest and debate in contemporary scholarship, and it is hoped that drawing our examples from Ezek 1 can contribute in some small way to this rapidly evolving discussion. ${ }^{5}$

2 So K. van der Toorn, Scribal Culture and the Making of the Hebrew Bible (Cambridge: Harvard University Press, 2007).

3 The genetic and developmental relationships between the Jewish mystical traditions and the classical rabbinic literature, Second Temple literature, and early Christian literature have yet to be fully explored and determined. The relationship of rabbinic literature, including the official Targumim, to the mystical traditions is particularly complex. The evidence is multifaceted and, at times, contradictory. It awaits comprehensive articulation.

4 Throughout the chapter, the targumic scribe choose to render the Hebrew חיה "beast, animal," not with the anticipated Aramaic cognate (חיתא), but with בריא, "creation, created being." This translation is unique to Ezekiel's two accounts of the merkabâa (Ezek 1 and 10). Outside of the vision texts, Targum Jonathan Ezekiel always offers חיתא as the equivalent to חיה; see 5:17; 14:15 bis, 21; 29:5; 31:13; 32:4; 33:27; 34:25; 38:20; 39:4, 17. To highlight this choice by the targumic scribe, I translate the Aramaic term בריא as "creature" and the Hebrew term חיה as "beast" or "animal." Generically, I refer to the beings as the hayyôt. On possible reasons for this choice, see D. Halperin, Faces of the Chariot (TSAJ 16; Tübingen: Mohr Siebeck, 1988), 128-29.

5 Recent publications include: P. Alexander, The Mystical Texts: Songs of the Sabbath Sacrifice and Related Manuscripts (CQS; London: T \& T Clark, 2006); R. Elior, Jewish Mysticism: The Infinite Expression of Freedom (Oxford: Littman Library of Jewish Civilization, 2007); eadem, "The Emergence of the Mystical Traditions of the Merkabah," in Paradise Now: Essays on Early Jewish and Christian Mysticism (ed. A. de Conick; Atlanta: Society of Biblical Literature, 2006), 83-103; eadem, The Three Temples: On the Emergence of Jewish Mysticism (Oxford: Littman Library of Jewish Civilization, 2005); F.V. Reiterer, T. Nicklas, and K. Schöpflin (eds.), Angels: the Concept of Celestial Beings - Origins, Development and Reception (Berlin and New York: de Gruyter, 2007); A. Orlov, From Apocalypticism to Merkabah Mysticism: Studies in the Slavonic Pseudepigrapha (JSJSup 114; Leiden: Brill, 2007); P. Schäfer, The Origins of Jewish Mysticism (Tübingen: Mohr Siebeck, 2009; repr. Princeton University Press, 2011); M. Swartz, "The Dead Sea Scrolls and later Jewish Magic and Mysticism," DSD 
The article will be developed in two parts. In part A, I examine six examples of expansion and rewording in Ezek 1. The discussion of each example will address all three of the aims that I have outlined: textual cues, exegetical choices, and hermeneutical assumptions. In part B, I offer a summative analysis of the nature of targumic exegesis and hermeneutics that, I contend, are characteristic of Targum Jonathan Ezekiel as a whole.

\section{A. Examples of Scribal Exegesis in Tg. J. Ezek $1^{6}$}

Ezekiel 1 falls into five parts. It begins with a historical prologue introducing the prophet and the circumstances of the revelation (vv.1-3). This is followed by descriptions of the celestial beasts, the hayyôt (vv. 4-14), and of the living wheels (vv. 15-21). The final segment (vv. 22-28) describes the throne-platform above the heads of the hayyôt and the being who sits upon the throne (vv. 22-28).

\section{Example 1: Sixty-four faces and two hundred fifty-six wings (Ezek 1:6)}

Ezekiel 1:6 is the first of three verses in 1:4-14 that have more than doubled in length in Targum Jonathan (vv. 6, 8, 14). In the MT, the verse is a terse seven words. Targum Jonathan is forty-seven words, most of which comprise two large expansions:

\begin{tabular}{|c|c|}
\hline Tg. J. Ezek 1:6 & MT Ezek 1:6 \\
\hline 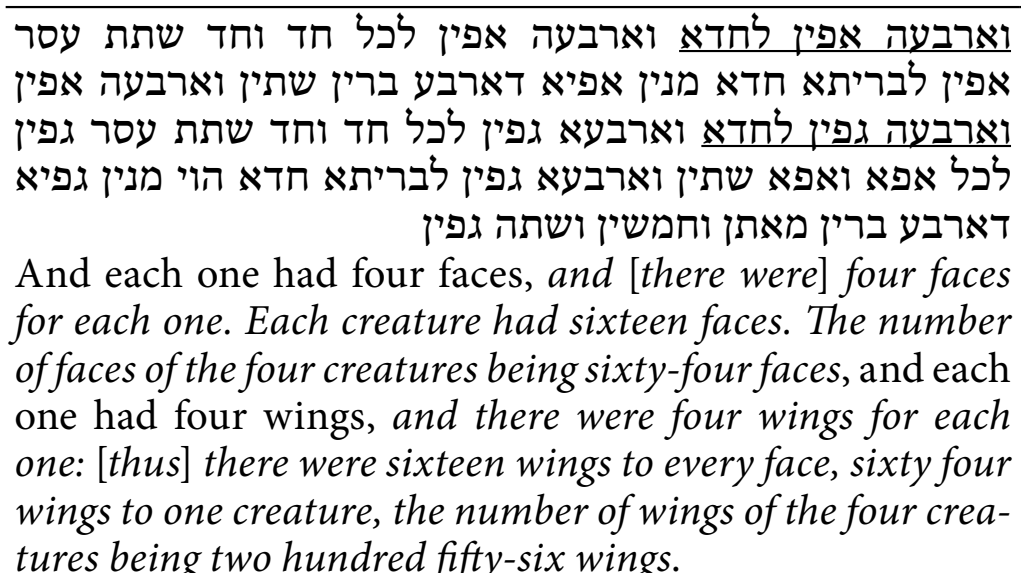 & $\begin{array}{l}\text { And each one had four } \\
\text { faces, and every one of } \\
\text { them had four wings }\end{array}$ \\
\hline
\end{tabular}

8 (2001): 182-93; A. Wood, Of Wings and Wheels: A Synthetic Study of Biblical Cherubim (BZAW 385; Berlin and New York: de Gruyter, 2008).

6 The translations of Targum Jonathan are adapted from S.H. Levey, The Targum of Ezekiel: Translated, with a Critical Introduction, Apparatus, and Notes (AramBib 13; Wilmington, Del.: Michael Glazier, 1987), in comparison with MS Or 1473 (Josep Ribera Florit, Targum Jonatán de los Profetas Posteriores en tradición babilónica: Ezequiel [Textos y estudios "Cardenal Cisneros"; de la Biblia Políglota Matritense 62; Madrid: Instituto de Filología, Consejo Superior de Ivestigaciones Científicas, 1997]) and Codex Reuchlinianus (P. de Lagarde, Prophetae Chaldaice, e fide codicis reuchliniani [Osnabrück: O. Zeller, 1967; repr. of 1872 ed.). Corresponding elements in Hebrew and Aramaic are underlined. Elements in the English translations of Targum Jonathan that are in italics are absent or different in MT. 
These enigmatic expansions have traditionally been dismissed as cases of "exuberant arithmetic" and compared with other supposed cases of midrashic numerical excess, like the fifty plagues against Egypt in the Passover Haggada. ${ }^{7}$ In effect, this explains away the large numbers. It does nothing to account for the relationship between the number of faces and wings. Read in light of the whole pericope, however, Targum Jonathan's expansions are seen to reflect considerable exegetical reflection. There are two connections that are essential to understanding the expansions. The first expansion, regarding the number of faces, is predicated upon a different division of the text than is reflected in the MT verse structure. The second expansion, regarding the wings, is conceptually intertwined with the first. The two expansions only make sense when their mutual dependence is recognized.

I begin with the second expansion, regarding the number of wings. The number of wings on the hayyôt is referenced twice in Ezek 1: in v. 6 and again in v. 11. Appreciating how the scribes dealt with v. 11 is essential to under-

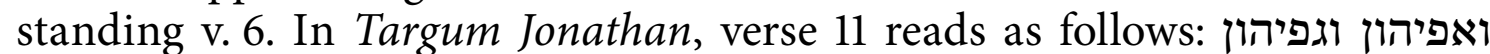
פרישין מלעילא לחדא תרתין מכונן חדא ותרתין מכסין גויתהון , "and their faces and their wings were outstretched upward; each [creature] had two extended to another [creature] and two covering their bodies." This rendering hews very close to the Hebrew, presenting as little difference between the two as is possible in a translation. Setting aside 1:6 for the moment, 1:11 shows that Targum Jonathan's scribes accepted that the hayyot, in fact, had four wings: two for flying and two for covering their bodies. Verse 6 was understood as a reference to additional wings, wings used for something other than flying and covering. To achieve this, the scribes construed the Hebrew syntax differently than modern commentaries and translations might do. The phrase לאחת להם, "and every one of them," in v. 6b was taken to refer, not to the hayyôt themselves but to the faces, as if the verse read, "every one of the faces had four wings." Thus, each face is surrounded by four wings. This reading is, syntactically speaking, possible. Its virtues, for the targumic scribes' purposes, are that it protects the integrity of the Hebrew syntax, and - in keeping with the midrashic assumption that there is no redundancy in scripture - it protects the uniqueness of vv. 6 and 11.

This does not yet produce two hundred fifty-six wings. That number was determined by the scribes' interpretation of the number of faces, which is found in the first expansion: "and four faces for each one: [thus] there were sixteen faces to each creature. The number of faces of the four creatures being sixty-four faces." Once again, the targumic scribes read the verse in the context of the wider pericope, influenced by verses 5 and 10 . The opening clause of v. 6 was understood in light of the preceding verse, and v. 5 was understood in light of v. 10 (the underlining in the English translations is for emphasis):

7 Halperin, Faces of the Chariot, 125-26. See also Levey, Targum of Ezekiel, 21.

Journal of Ancient Judaism, 5. Jg., 393-414, ISSN: 1869-3296 (print), 2196-7954 (online) (c) 2014 Vandenhoeck \& Ruprecht GmbH \& Co. KG, Göttingen 


\begin{tabular}{|c|c|}
\hline g. J. Ezek 1:5-6a, 10 & MT Ezek 1:5-6a, 10 \\
\hline אנשא להון: וארבעת ארבע אפרין לחדא ודין חזויהון דמות & אדם להנהוכה: ואמות ארבעה פנים לאחת וזה מראיהן דמות \\
\hline מימינא לארבעת אפיהון ואפי אנשא ואפ עי עביד מסמלא עביא & 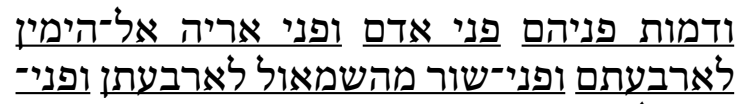 \\
\hline א לארבעתיהון: & נַשר לארבעתן: \\
\hline $\begin{array}{l}\text { And in its midst was the likeness of four } \\
\text { creatures, and this was their appearance: } \\
\text { they had the likeness of a human, and } \\
\text { each one had four faces ... } \\
\text { And regarding the likeness of their faces, } \\
\text { [the four of them had] the face of a hu- } \\
\text { man; and the four of them had a face of a } \\
\text { lion fashioned on the right side; and the } \\
\text { four of them had a face of an ox fashioned } \\
\text { on the left side; and the four of them had }\end{array}$ & $\begin{array}{l}\text { And in its midst was the likeness of four } \\
\text { beasts, and this was their appearance: } \\
\text { they had the likeness of a human, and } \\
\text { each one had four faces ... } \\
\text { And regarding the likeness of their faces, } \\
\text { [the four of them had] the face of a hu- } \\
\text { man, and the four of them had a face of } \\
\text { a lion on the right side; and the four of } \\
\text { them had the face of an ox on the left } \\
\text { side; and the four of them had the face of } \\
\text { an eagle. }\end{array}$ \\
\hline
\end{tabular}

The essential point from v. 10 that bears upon vv. 5-6a is that the hayyôt have a different face for each cardinal direction, and one is the face of אדם, a "human." The scribe's first choice was to understand the term אדם in v. 5 as coextensive with the term in v. 10: both refer to a face on the creature. The phrase דמות אנשא "likeness of a human," in v. 5, then, refers to one of the faces, not to the characteristic humanoid shape of the creature, as it is commonly understood today. ${ }^{8}$ The second exegetical decision, was to construe v. 6 as a ומגוה רמות ארבע: continuation of v. 5, as if the verse division was not relevant ברין ודין חזויהון דמות אנשא להון וארבעה אפין לחדא ,And in its midst was the likeness of four creatures, and this was their appearance: they had the likeness [face] of a human, and each one [face] had four faces ..."9 (This interpretation anticipates v. 10, as I have argued.) The interpretation of חדא, "each one," as a face, presupposes the multiple faces revealed in $\mathrm{v}$. 10 . This expectancy is clearly manifest in the expansion, the mathematics of which are now coherent: "and each one [i.e., face] had four faces and [there were] four faces for each one [i. e., each cardinal direction had four faces]: thus there were sixteen faces to each creature, the [total] number of faces of the four creatures [combined] being sixty-four faces." This also makes sense of the mathematics in the second expansion: "every one of them [i. e., every face] had four wings and [there were] four wings for each one [i. e., each of the creatures' faces]: thus there were

8 E.g., M. Greenberg, Ezekiel 1-20 (AB 22; New York: Doubleday, 1983), 44; W. Zimmerli, Ezekiel 1: A Commentary on the Book of the Prophet Ezekiel, Chapters 1-24 (Hermeneia; Philadelphia: Fortress, 1979), 120.

9 For similar examples of alternative verse divisions in rabbinic midrash see A. Samely, "Scripture's Implicature: The Midrashic Assumptions of Relevance and Consistency," JSS 36 (1992): 167-205. The influence of this article on the present study is pronounced and can be detected at many turns. 
sixteen wings to every single face [i. e., each four-fold face], sixty-four wings to each creature, the [total] number of wings of the four creatures [combined] being two hundred and fifty-six wings."

Hekhalot Zutarti, which appears to be dependent upon Tg. J. Ezek 1, contains a similar description of the hayyôt. Note, in particular, the element in italics:

Each one has four faces, four faces to a face; four faces for each face; sixteen faces for each face; sixty-four faces for each creature. The total number of faces of the four creatures is two hundred and fifty-six. Each wing has four wings, four wings to a wing; four wings for each wing; sixteen wings for each wing; sixty-four wings for each creature. The total number of wings of the four creatures is two hundred and fifty-six. ${ }^{10}$

Hekhalot Zutarti accounts for the redundancy in Ezek 1, regarding the number of faces and wings on each creature (Ezek 1.6, 10-11), by means of multiplication. Verse 6 attributes four faces to each creature; verse 10 does the same. Rather than considering verse 10 a repetition, it is considered a multiple: four faces for each of the four faces. The same logic is applied to the wings. The exegetical reasoning evident in this pericope, though not identical to it, is congruent with the reasoning manifest in $\mathrm{Tg}$. J. Ezek 1 . These figures, then, are not the product of an imaginative or obsessive concern with large numbers. The numbers of the faces and wings are the product of careful exegetical reasoning, reasoning based upon the features of the larger context and on the assumption that every scriptural predication is unique and meaningful. ${ }^{11}$

\section{Example 2: Straight feet and round hooves (Ezek 1:7)}

Following the extensive expansions to v. 6, Targum Jonathan's rewriting of v. 7 appears quite restrained. Nonetheless, the alterations to the verse have received considerable attention:

\begin{tabular}{|c|c|}
\hline Tg. J. Ezek 1:7 & MT Ezek 1:7 \\
\hline ורגליהון רגלבין כַיונן ופרסת רגליהון כפרסת & ורגליהם רגל ישרה וכף רגליהם ככף רגל עגל \\
\hline רגלין סגלגלן ומזיען עלמא במהכהון ומנצנצן & ונצצצים כעין נהשת קלל: \\
\hline כעין נחש מצלהב: & \\
\hline $\begin{array}{l}\text { And their feet were straight feet, and } \\
\text { their soles were like round soles. And } \\
\text { they shook the world when they moved, } \\
\text { and they blazed like an appearance of } \\
\text { burnished bronze. }\end{array}$ & $\begin{array}{l}\text { And their feet were a straight foot, },^{12} \text { and } \\
\text { the sole of their feet was like the sole of } \\
\text { a calf's foot, and they sparkled like the } \\
\text { colour of burnished bronze. }\end{array}$ \\
\hline
\end{tabular}

10 P. Schäfer, Synopse zur Hekhalot-Literatur (TSAJ 2; J.C. B. Mohr: Tübingen, 1981), § 353-55.

11 The targumic scribe and the composer(s) of Hekhalot Zutarti may have been influenced toward their interpretations by Ezek 1:8, which could be construed to mean that each of the four sides had multiple wings and faces.

12 This could indicate that there was no angle at the ankle, as there is on a human foot, or, perhaps, that "their legs were a single straight/rigid leg." The Targumists appear to have chosen the first option. 
The rewording that concerns us here is the translation of ככרף רגל עגלי רגל רגל, "like the sole of a calf's foot," with כפרסת רגלין סגלגלן, "like round soles." There are two

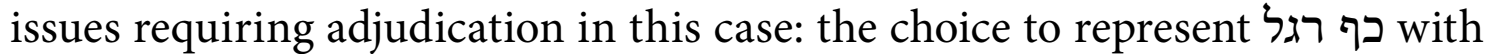

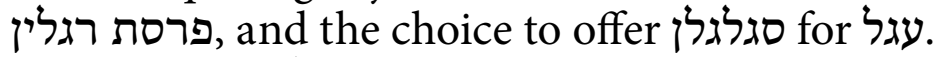

Regarding פרסת רגלין, Targum Jonathan smooths out the syntax by rendering the singular noun רגלין רגלין (Heb) as plural (Aram). Otherwise, the transla-

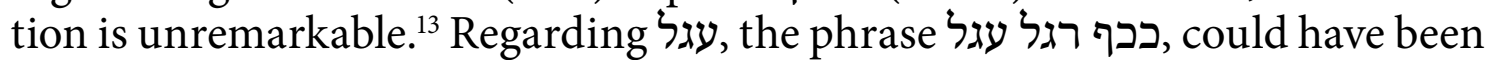

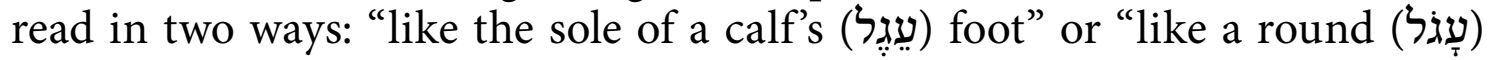
sole." The targumic scribes concluded that the Hebrew simile denotes a round foot. They then rendered the word עגל with a graphically similar, semantically concordant word. They offered a reduplicating adjective from סגל עגל (Aram), "be round," as their equivalent for עגל. Thus, the targumic scribes' efforts reflect an attempt to articulate the analogy expressed in the Hebrew. Put another way, the scribes are concerned to represent the sense of the Hebrew (as they understood it) clearly and accurately.

Both Levey and Halperin argue that the Aramaic rendering, in particular the elimination of עגל "calf," represents an attempt to "banish the calf from the text," to sterilize the text of any reference that might evoke the golden calves of Sinai or Jeroboam (Exod 32; 1 Kgs 12.25-33)..$^{15}$ Both take their cue from $b$. Hag. 13b, which explains the absence of the calf's face in Ezek 10:14 as follows: "Resh Lakish said: Ezekiel entreated concerning it [the calf's face] and changed it into a cherub. He said before Him: Lord of the universe, shall an accuser become an advocate?" In early Jewish texts, there is, without doubt, a palpable unease with any reference or allusion to a calf image. ${ }^{16}$ Whether

13 The choice to represent כרס with the Aramaic lexeme פרסה "hoof, sole," appears unremarkable inasmuch as פרסה is commonly used to represent both Hebrew terms, פרסה (מרסה, "hoof," and כף "(Heb) in Josh 1:3; 3:13; 4:18; 2 Sam 14:25; 1 Kgs 5:17; 2 Kgs 9:35; 19:24; Isa 37:25; 60:14; Ezek 1:7; פרסה :: פרסה (Aram) (Heb) in Isa 5:28; Jer 47:3; Ezek 26:11; 32:13. Collocation: Josh 14:9; 2 Sam 22:39; Jer 18:22. Wherever Targum Jona-

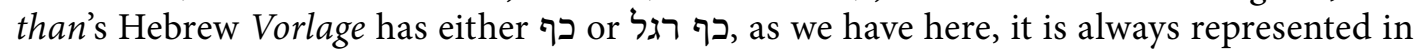
the Targum by פרסת רגל, a collocation which merely means "sole" or "sole of the foot" (Josh 1:3; 3:3; 4:18; 14:9; 2 Sam 14:25; 22:39; 1 Kgs 5:17; 2 Kgs 19:24; Isa 37:25; 60:14; Jer 18:22; Ezek 1:7). One exception is found in $\mathrm{Tg}$. Neof. Exod 10:26, "Our cattle will also go with us. Not a hoof (פרסת רגל) will be left behind." The MT reads "Our livestock also must go with us; not a hoof (פרסה) shall be left behind."

14 Representing a given lexeme by means of another lexeme that shares two out of three root consonants is not infrequent in rabbinic literature. For examples of this species of 'al tiqre see, e. g., m. Ber. 9:5 (9); m. Meg. 4:9; m. San. 6:5 (2). As Abraham Geiger noted, the same change appears in a' (Urschrift und Übersetzungen der Bibel in ihrer Abhängigkeit von der inner Entwicklung des Judentums [Frankfurt: Madda, 1928], 343). Pinkhos Churgin does not accept that this is deliberate. He considers this a true variant, a difference between Targum Jonathan's Vorlage and the proto-MT, but he does not offer a reconstruction of Targum Jonathan's

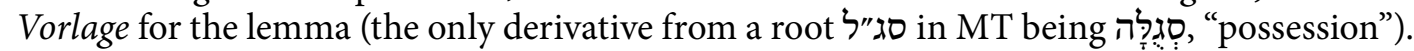
See Churgin, Targum Jonathan to the Prophets (New Haven: Yale University Press, 1927), 62.

15 Halperin, Faces, 128; Levey, Targum of Ezekiel, 20 and 21 n. 6-7.

16 See also Lev. Rab. 27:3 and Pesiq. Rab Kah. 9:3. In both texts, the seraphim (Isa 6:2) covered their feet to conceal their resemblance to the calf (citing Ezek 1:7 and Exod 32:8). This con- 
or not this concern has motivated the choices of the targumic scribes, in this case, or whether their translation merely represents an existing reading tradition is impossible to determine. ${ }^{17}$

\section{Example 3: Raking out burning coals of fire (Ezek 1:8)}

Verse eight is the third verse to undergo major expansion. In this case, the expansion grants the hayyôt a role in the judgment of the wicked.

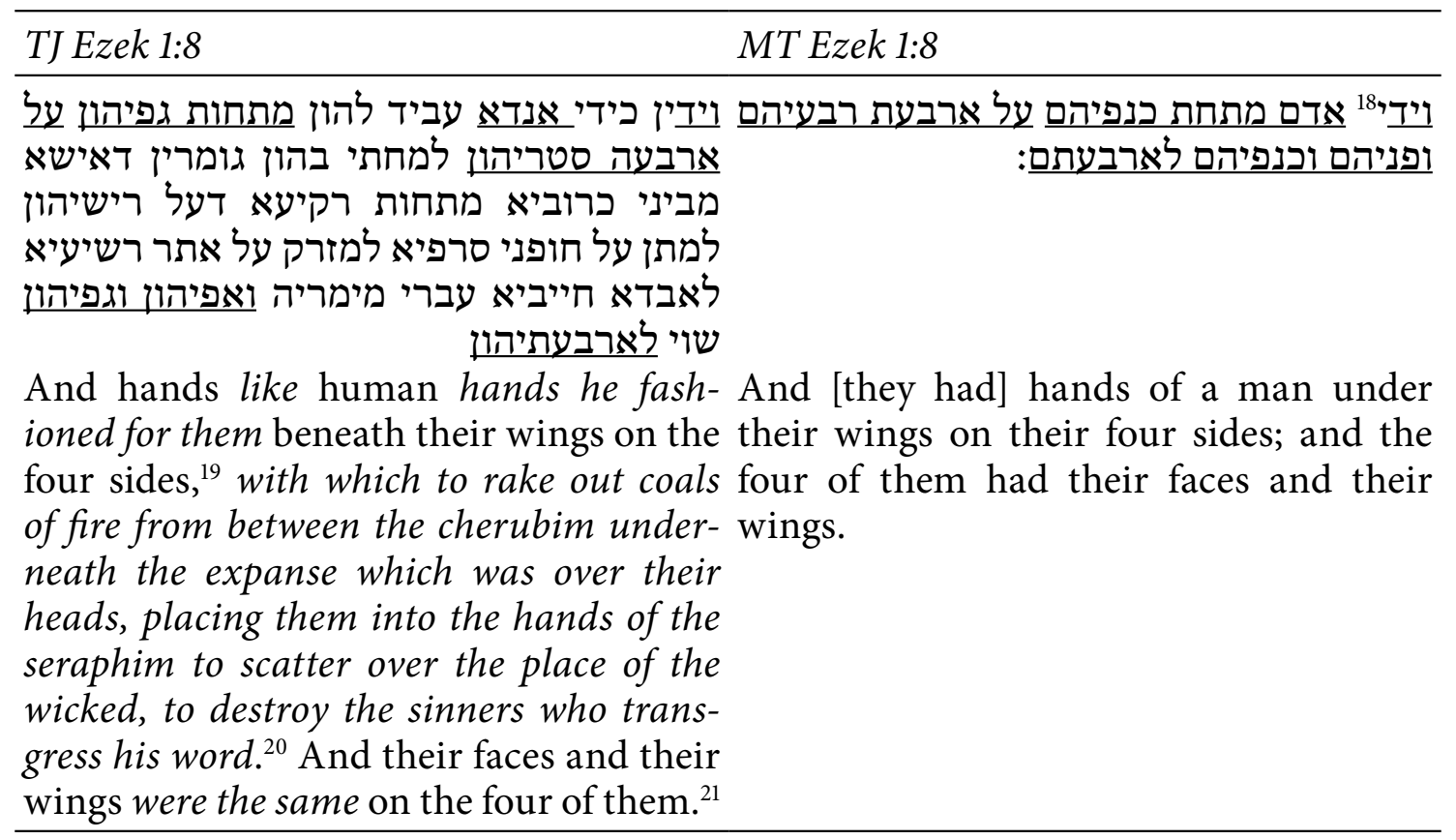

cern was not universal among the sages, as can be seen, for example, in the description of the angel in $b$. Yom. 19b.

17 It has been suggested that the pairing of Ezek 1 as the haftarah for Exod 19-20 during Shavu'ot influenced the translation of Targum Jonathan, in that the reading of Exod 19-20 might evoke the golden calf story in the minds of synagogue-goers. Whether or not later liturgical use had any influence on the translation process, however, is entirely speculative if not dubious.

18 The Ketiv is וידו, but the Qere is וידי Targum Jonathan followed the Qere; b. Pes. 119a adopts the Ketiv, "his hand," understood as the hand of God extended to welcome repentant sinners. My translation of MT follows the Qere.

19 Targum Jonathan's סטריהון is a clarification of the MT. Whereas MT has "on the four (ארבעת) of their four [sides] (רבעיהם)," Targum Jonathan renders "on the four (רבעה), [that is] their sides (סטריהות)."

20 Ms H. 116 adds ולקבלא בהון תיובתא דכל בעלי תיבתא, "and to receive with them the repentance of all penitent sinners" in keeping with the Qere noted in n. 18.

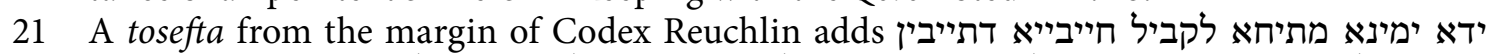
בתיובא לזכאה יתהון ביום דינא לאחסנותהון חיי עלמא וידא שמאלא מתיחא למיחתי בה גומרין דאשא ו וגו, "the right hand extended toward the sinners who have returned in repentance, to declare them innocent on the day of judgment, to enable them to possess eternal life; and the left hand extended to take out burning coals of fire, etc." This comment, like the addition to MS H. 116 in n. 20, above, accounts for the change from singular "hand" (MT) to plural "hands" 
My interest here is the large expansion (למחתי ... מימריה) in which the scribes explain the need for hands. The plus was inserted between the two clauses that made up the Hebrew source text: וידו אדם מתחת כנפיהם על ארבעת רבעיהם, "and they had hands of a man under their wings on their four sides," and ופניהם וכנפיהם לארבעתם, "and the four of them had their faces and their wings." The syntax of the Hebrew original was preserved in the Aramaic version. If the expansion were removed, the syntax of the Targum would mirror that of its Hebrew archetype.

The expansion was composed of locutions borrowed from Ezek 10:2; 1:22; and 10:6-7, conflated in a complex patchwork (elements from each source are marked differently):

TJ 1:8

MT 10:2

MT 1:22

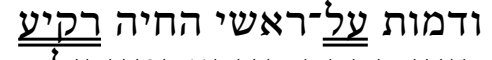

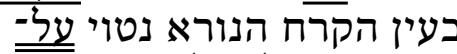
ראשיהם מלמעלה: כתוראו

MT 10:6-7
למחתי בהון גומרין דאישא

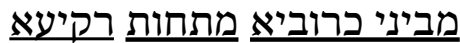
דעל רישיהון למתן על חופני רופי

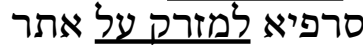

רשיעיא

ויאמר אל־האיש לבש הבדים

ויאמר בא אל-בינות לגלגל ליבלי

אל־תחת לכרוב ומלא חפניד לגיניד גחלי־אש מבינות לכרבים וזרק על־העיר ויבא לעיני:
ויהי בצותו את־האיש לבשהבדים לאמר קח אש מבינות לבינות

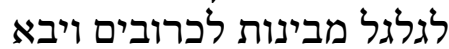

ויעמד אצל האופן: וישלח

הכרוב את־ידו מבינות אליפות לכרובים אל־האש אשר בינות

הכרובים וישא ויתן אל־חפני ביתות לבש הבדים ויקח ויצא:

... with which to rake out coals of fire from between the cherubim underneath the sky which was over their heads, placing them into the hands of the seraphim to scatter over the place of the wicked And he spoke to the man clothed with linen, and he said, "Come in between the wheel, under the cherub, and fill your palm with coals of fire from between the cherubim, and scatter [them] over the city. And he went in within my sight.

And the likeness above the heads of the beast was a platform as the appearance of afraid ice, stretched out over their heads above.

And it came to pass, when he commanded the man clothed with linen, saying, "Take fire from between the wheel, from between the cherubim," that he came and he stood beside the wheel. 7. And the cherub stretched forth his hand from between the cherubim unto the fire, which was between the cherubim, and took [some], and gave [it] into the hands of he who was clothed with linen. And he took, and he went out.

The expansion excerpts and recombines elements from all four verses (1:22; 10:2, 6-7) as follows:

1. Three prepositional phrases - אל־תחת לכרוב, "underneath the cherub" (10:2), על־ראשיהם על ... עלקיע, "above ... the sky" (1:22), above their heads" (1:22) - were recombined as מתחות רקיעא דעל רישיהון, "underneath the sky which was over their heads."

(Targum Jonathan). That is, one hand is used to dole out the tools of judgment on sinners, and the other hand beckons to the penitent, receiving them into the world to come. 
2. The Hebrew phrase גחלי-אש מבינות לכרבים (coals of fire from between the cherubim" (10:2), was simply rendered into Aramaic and inserted into the verse (cf. 10:6-7). That the phrase is borrowed from Ezek 10 is betrayed by the term כרוביא, "cherubim," which is never used in the MT of Ezek 1. Nor is it employed in Tg. J. Ezek 1 apart from this verse. ${ }^{22}$

3. The clauses למתן על חופני סרפיא למזרק על אתר רשיעיא, "placing them into the hands of the seraphim to sprinkle on the place of the wicked," combine

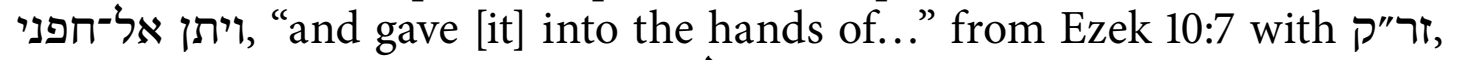
"scatter," from Ezek 10:2. MT's זרק על־העיר "scatter over the city" (10:2) was too specific for Targum Jonathan's purposes. Targum Jonathan describes the regular duties of the hayyôt, so the clause was revised to the more generic מזרק על אתר רשיעיא, "scatter over the place of the wicked."

4. The final clause in this large expansion, לאבדא חייביא עברי מימריה, "to destroy the sinners who transgress his word," appears to be the only part of the expansion that is entirely the creation of a targumic scribe.

The care that was taken in constructing this complex expansion underlines its importance. The expansion is the product of a whole constellation of exegetical decisions on the part of the targumic scribes. Of these decisions, the central one is the perceived need to assign a task to the hayyot. In MT, they have no role or function apart from supporting the divine throne, and even that role is implicit. Nonetheless, they move about (vv. 12,14), and they have limbs with which to act: hands, feet, and wings (esp. vv. 6-8). Hands, in particular, imply actions. Movements imply tasks. Thus, the description of the hayyôt in MT begs the question of the function of the hayyot. The targumic scribes have filled this gap and rendered explicit that which they viewed to be implicit in the Hebrew. ${ }^{23}$ Here in v. 8 , we are introduced to the function of the hayyôt that requires hands: taking part in the destruction of the wicked. ${ }^{24}$ This role was not invented, as we have seen. It was adopted from 10:1-7. The hayyôt dole out coals of fire, which they tend and keep, to the seraphim who use them to destroy the wicked (cf. Gen 19:17-24; Ezek 38:22).

The second exegetical operation within this expansion is concerned with one element of the expansion that was derived from Ezek 10. In the MT of Ezek 10:6-7, the hayyôt offer their coals of fire to "a man dressed in linen" who was ordered to scatter them over Jerusalem. Targum Jonathan 1:8 identifies this

22 Halperin contends that the "translator has forgotten that the hayyot and the cherubim are supposed to be the same" (Faces of the Chariot, 124). However, the targumic scribes nowhere asserted that the two are different. The scribes used כרוביא, $\underline{k}^{e} r \hat{u} b a y \vec{a}$, not out of forgetfulness but because it is part of a locution borrowed from Ezek 10:7, which the scribes rendered faithfully.

23 The terms "gap" and "gapping" (as well as "blank" and "place of indeterminacy") are used in a variety of ways in literary theory and linguistics. What I indicate by the term "gap" is an instance in which an item, event, or individual is introduced but is not accounted for or explained.

24 Another function is assigned to the hayyôt in 1:14, which is introduced in the fifth example. 
man as a particular species of celestial being, a seraph. ${ }^{25}$ This association is comprehensible, inasmuch as it is the seraph in Isa 6:6-7 who both deals with the heavenly coals of fire and employs it to eradicate sin. Targum Jonathan 1:8, at once, distinguishes between Ezekiel's hayyôt and Isaiah's seraphim and creates coherence between the two texts by assigning complementary roles to the two types of hybrid beings.

The ingenuity and effort that the targumic scribes put into coordinating the parts of Ezek 1 with one another and with Ezek 10 and Isa 6 is a clear indication of their commitment to the notion of the coherence of scriptures and the weight that notion bore in their exegetical considerations.

\section{Example 4:רוח > רעו (Ezek 1:12)}

Targum Jonathan Ezek 1:12 reads, "And [each] creature went straight ahead. They went to the place which it was the will to go. They did not turn as they moved." Of particular interest in this verse is the rewording of Hebrew רוח, "spirit." Instead of offering the expected Aramaic cognate, רוח, as the scribes did in 1:20 and 21, they chose, in this case, to reword their text with a visually similar grapheme רעו, "desire, will." To achieve the rewording רו"ח > רע"ו, heth was exchanged for 'ayin and the last two radicals of the root were metathesized. Both of these are common graphic alterations. ${ }^{26}$ The same rewording occurs twice in v. 20, and the noun רעוה appears in the expansions to v. 14, underlining the importance of the choice to the scribes' interpretive strategy.

The rewording רו"ח > רע"ו reflects the scribes' understanding of the semantic potential of רוח. The same rewording also occurs in Isa 34:16 and Zech 6:8. In Isa 34:16, the choice clarifies the sense of the Hebrew Vorlage. The chapter is an oracle against Edom, addressed to the nations of the earth, in which YHWH summons various wild animals to inhabit the ruins of Edom following its destruction. In the MT, Isa 34:16 reads: "for the mouth of the Lord has commanded, and his spirit (רוח) has gathered them." Targum Jonathan renders with "For by his Memra they will be gathered, and by his will (רע"ו they will draw near." "Will," in this case, appears a likely equivalent for "spirit," expressing the sense of the MT plainly. In MT Zech 6:8, four chariots are sent

25 This accords with the early Jewish mystical texts, in which the cherubim, hayyôt, seraphim, and 'ōphānîm are different kinds of angelic beings with different functions. See P. Schäfer, The Hidden and Manifest God: Same Major Themes in Early Jewish Mysticism (trans. A. Pomerance; SUNY Series in Judaica; Albany: State University of New York Press, 1992).

26 See I. Heinemann, The Methods of the Aggadah (3d ed.; Jerusalem: Magnes, 1954), 127-29 (Hebrew). The interchange of heth and 'ayin is particularly common in Samaritan sources and Galilean Aramaic. See R. Macuch, Grammatik des samaritanischen Hebräisch (Berlin: de Gruyter, 1969), 32; Z. Ben-Hayyim, The Literary and Oral Tradition of Hebrew and Aramaic among the Samaritans (5 vols.; Jerusalem: Bialik, 1957-77), 5.25-29 (Hebrew); idem, A Grammar of Samaritan Hebrew: Based on the Recitation of the Law in Comparison with the Tiberian and Other Jewish Traditions (Jerusalem: Magnes and Winona lake: Eisenbrauns, 2000), § 1.1.8. 
to "set my spirit at rest in the North country." The highly ambiguous Hebrew clause הניחו את־רוחי רעידות "set my spirit at rest," is rendered in Targum Jonathan as, עבידו ית רעותי "do my will.” Though still well within the bounds of the semantic potential of the MT, the rewording in this case serves to clarify and restrict possible interpretations of Zech 6:8.

Here in Ezek 1, more complex issues are in play. The scribes' choices are varied. In reference to the hayyôt and the wheels, the targumic scribes chose to render רו" רע in vv. 12 and 20 (bis), and included רעו"ו in the expansion רו"ח רo v. 14. However, they chose Aramaic as the equivalent for Hebrew in 1:20, 21; and 10:17. ${ }^{27}$ What distinguishes between these cases is the identity of the spirit. In all the cases where רו רו the wheels: "for a spirit like that of the creatures was in the wheels" (1:20b, 21b; 10:17b similarly). This affirmation that the wheels are living beings, possessing a spirit like that of the creatures, was unobjectionable to the targumic scribes. They were not so sanguine with respect to the hayyôt. Where the Hebrew uses in reference to the hayyôt, the scribes chose instead to reword the text, translating with רע"

And [each] creature went straight ahead. They went to the place which it was the will to go ... (1:12a)

And the creatures, when they are sent to do the will of their Master ... (1:14)

To the place which it was the will to go there, there they [the hayyott] would go; it was the will to go there ... (1:20a)

The Targum never attributes the spirit to the hayyott. In these three cases, the articulation of the Hebrew text indicates that the spirit is independent of the hayyôt, exerting influence on them to direct their movements. This, almost certainly, would have to be identified as the divine spirit. Rabbinic tradition, however, held that Haggai, Zechariah, and Malachi were the last prophets (Yoma 9a; Tos. Sot. 13:2). The rabbis took exception to the notion that revelation was imparted through humans or angels privy to the divine spirit. The targumic scribes made efforts to avoid the impression that the hayyôt were in possession of the divine spirit able to confer revelation (per Joel 3:1-5). That this reflects a concern with revelation, specifically, is suggested by v. 25 . Verse 25 explicitly isolates the creatures from any participation in divine revelation: "And at such a time, when it was his will to make the sound of the revelation audible to his servants the prophets of Israel, there was a voice which was heard from above the sky, which was above their heads. When they stood still, their wings became silent before the revelation." Thus, by making creative use of the translationchoices available to them, the targumic scribes successfully directed the interpretation of Ezek 1 down accepted lines; assuring that readers or auditors

27 Aramaic רוח appears for Hebrew in most cases in Ezekiel: 1:4, 20, 21; 2:2; 3:12, 14 bis, $24 ; 5: 2,10,12 ; 8: 3 ; 10: 17 ; 11: 1,5,19,24$ bis; $12: 14 ; 13: 11,13 ; 17: 10,21 ; 18: 31 ; 19: 12 ; 21: 12 ; 27: 26$; $36: 26,27 ; 37: 1,5,6,8,9[4 \times], 10,14 ; 39: 29 ; 42: 16,17,18,19,20 ; 43: 5$. I am not considering 1:4 in the example above where רוח refers to the "storm wind" from the north. 
arrived at the "correct" interpretation: the creatures move in accordance with the divine will rather than being in possession of the divine sprit.

\section{Example 5: To do the will of their Master (Ezek 1:14)}

The pericope's third large expansion appears in v. 14. Like the expansion in v. 8, it describes one of the duties of the hayyôt:

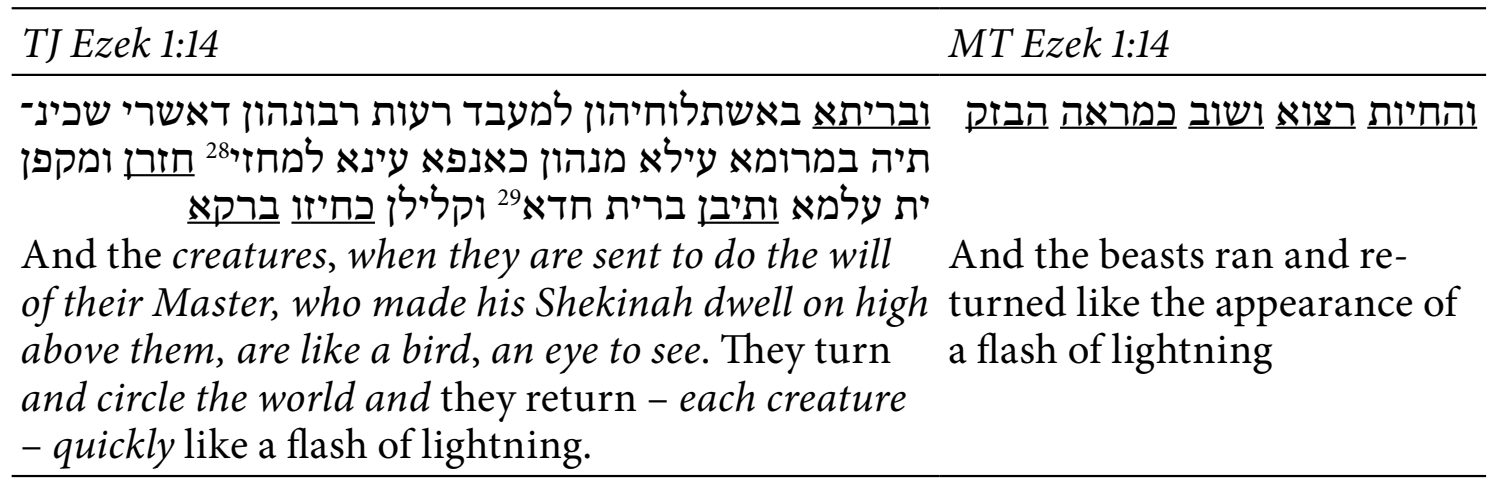

Targum Jonathan expands between four of the five words that make up the Hebrew verse. The scribe added new material between the subject and predicate רצוא / (והחיות / רצוא ושוב), between the two verbs that make up the predicate (ושוב), and between the predicate and the prepositional phrase which modifies it (רצוא ושוב / כמראה הבזק). The rewritten verse is, nonetheless, nearly seamless. Apart from the awkward ברית חדא, it is syntactically cohesive, and, when the expansions are removed, it still mirrors the syntax of the Hebrew.

The coordinated expansions are remarkably complex. Their main purpose is to assign another role to the hayyôt in harmony with other scriptures and with rabbinic reflection on the hayyôt and their duties. Due to the expansions' complexities, these choices and assumptions are perhaps best explained as a series of interrelated points:

1. The three expansions, taken together, explain a gap in the Hebrew text. The terse MT text declares that the hayyôt, when they move, are swift as lighting. The Targum explains when and why the hayyot might move. In this case, the Targumist has something different in view than simply porting the divine throne wherever God desires. The Targumist assumes the divine

28 The clause כאנפא עינא למחזיis difficult. (The Second Rabbinic Bible, Antwerp Polyglot, and Kimhi read באנפא.) For translation possibilities see S. H. Levey, "The Targum to Ezekiel," HUCA 46 (1975), 153 n. 54; idem, Targum of Ezekiel, 21-22, n. 11. The line echoes the rabbinic tradition that angels were created on the fifth day: "R. Hanina said, 'They were created on the fifth day, for it is written, "And let winged creatures fly above the earth" (Gen 1:20), and it is written, "And with two he flew" (Isa 6:2)"” (Gen. Rab. 1:3).

29 The clause ותיבן ברית חדא is problematic. The verb is plural but the subject is singular (mechanically: they returned - a creature - one/each). The rabbinic Bibles have the subject and verb in concord, reading בריתא. This solution is not perfect. To achieve something like "the creatures returned as one," "singularly," or "one by one," we would anticipate כחדא, לחדא, or חדא rather than חדית חדא rat. Tg. J. Ezek 1:6). Perhaps the phrase a vertical dittography in the Targum from v. 6. 
throne is (or can be) stationary. The hayyôt, in this case, are depicted moving away from it, "sent (של"ח) to do the will of their master." 30 The errand they are sent on is described in the expansion: "the creatures, when they are sent to do the will of their Master, who makes his Shekinah dwell on high above them, are like a bird, an eye to see. They turn and circle the world and they return - each creature - quickly like a flash of lightning." The hayyôt are sent out, round the earth, to carry out the divine will.

2. Thus, in Targum Jonathan, the hayyôt have been assigned a second role, in addition to their custody of the heavenly fire (v. 8). That role is to circumnavigate the earth, high like birds, swift like lightning, to do God's will. This, presumably, could entail any sort of task.

The use of the term רעו, "will," in this case illuminates the reasons for the rewording we described in vv. 12 and 20. In MT 1:12, the creatures move wherever the spirit (רוח) dictates. In Tg. J. 1:12 the creatures move in accordance with the will (רעו). Verse 14 discloses this action as service to the divine will.

3. The new task that has been assigned to the hayyôt - circling the world and reporting on its inhabitants - was not invented by a targumic scribe. It was drawn from the visions of the horses in Zech 1:8-11 and 6:1-8. In Zech 1, the horses patrol the earth and report on it to the deity. In MT Zech 6:8, chariots are sent to "set my spirit at rest in the North country." The Hebrew clause עבידו, הניחו את־רוחי "הet my spirit at rest," is rendered in Targum Jonathan as "do my will."31 Apart from one instance (Isa 34:16), this equation, רוח : רעות רות is unique to Tg. J. Ezek and Zech, and confirms that the role of the hayyôt has been coordinated with that of the horses/chariots in Tg. J. Zech. ${ }^{32}$ What the hayyôt do to "carry out the divine will," however, is never made explicit.

4. Finally, the expansion accounts for an apparent redundancy in the MT. Verse 14 is absent in LXX. The Hebrew verse is an expansion. It includes elements from v. 13 (יצ"א + ברק), colored in light of Dan 10:6, and it addresses the movement of the hayyôt, which was already described in Ezek 1:9, 12-13. ${ }^{33}$ Once again, the hermeneutical assumption that there is no repetition in scripture

30 For the same notion - an angel doing the will of the Lord - see Incantation Bowl 14:6 = CAIB 23 (C. D. Isbell, Corpus of the Aramaic Incantation Bowls [Missoula: Scholars, 1975]).

31 Based on the similarities to Zechariah's horses/chariots, it would appear that $\mathrm{Tg}$. J. Ezek borrowed from $\mathrm{Tg}$. J. Zech, and not vice versa. Tg. J. Zechariah may have been influenced by Isa 34:16, where the equation רעו : also appears.

32 Halperin attributes the appearance of "will" here in $\mathrm{Tg}$. J. Ezek 1:14 to a misunderstanding on the part of a targumic scribe. The scribe, he asserts took רצ"א as a hybrid of רצ"ה, "desire," and "ור, "run" (Faces, 123; cf. Kimhi). The difficulty is that the interpretation of "spirit" as "will" appears in Tg. J. Ezek 1:12, 14, and 20 bis. רצ" only appears in one of those instances, 1:14, whereas רוח appears in the MT in every case, and in Tg. J. Zeph 6:8 (for MT's רוח כרמח).

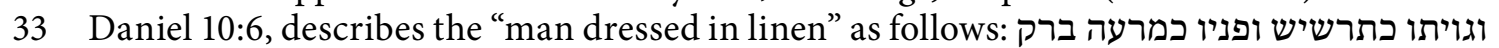
"His body was like "ועיניו כלפידי אש וזרעתיו ומרגלתיו כעין נחשת קלל וקול דבריו כקול המון: beryl, his face like lighing, his eyes like flaming torches, his arms and legs like the gleam of burnished bronze, and the sound of his words like the roar of a multitude." The redactors of the proto-MT, recognizing that Dan 10:6 was composed almost entirely of locutions borrowed from Ezek 1, assimilated Ezek 1 to Dan 10:6. On this phenomenon, see Y. Zakovitch, 
appears to be in play. Ezekiel 1:14, thereby, must say something unique, and that something has been made plain by the Targumist.

\section{Example 6: Praises of the Celestial hayyôt (Ezek 1:24-25)}

In the Hebrew text, Ezek 1:24-25 addresses two sounds: the sound of the wings of the hayyôt (v. 24) and the sound from above the platform (v. 25). Verse 24 describes the noise (קול) made by the flapping wings, and the posture of their wings when the hayyôt are not flying. Verse 25 describes a voice (קול) emanating from above the platform, before reiterating that the hayyôt relax their wings when not flying. It is a disjointed series of topic sentences in Hebrew. Targum Jonathan, through a succession of small expansions, creates logical connections between the parts of the two verses and explains what is communicated by the sound of the wings and by the voice.

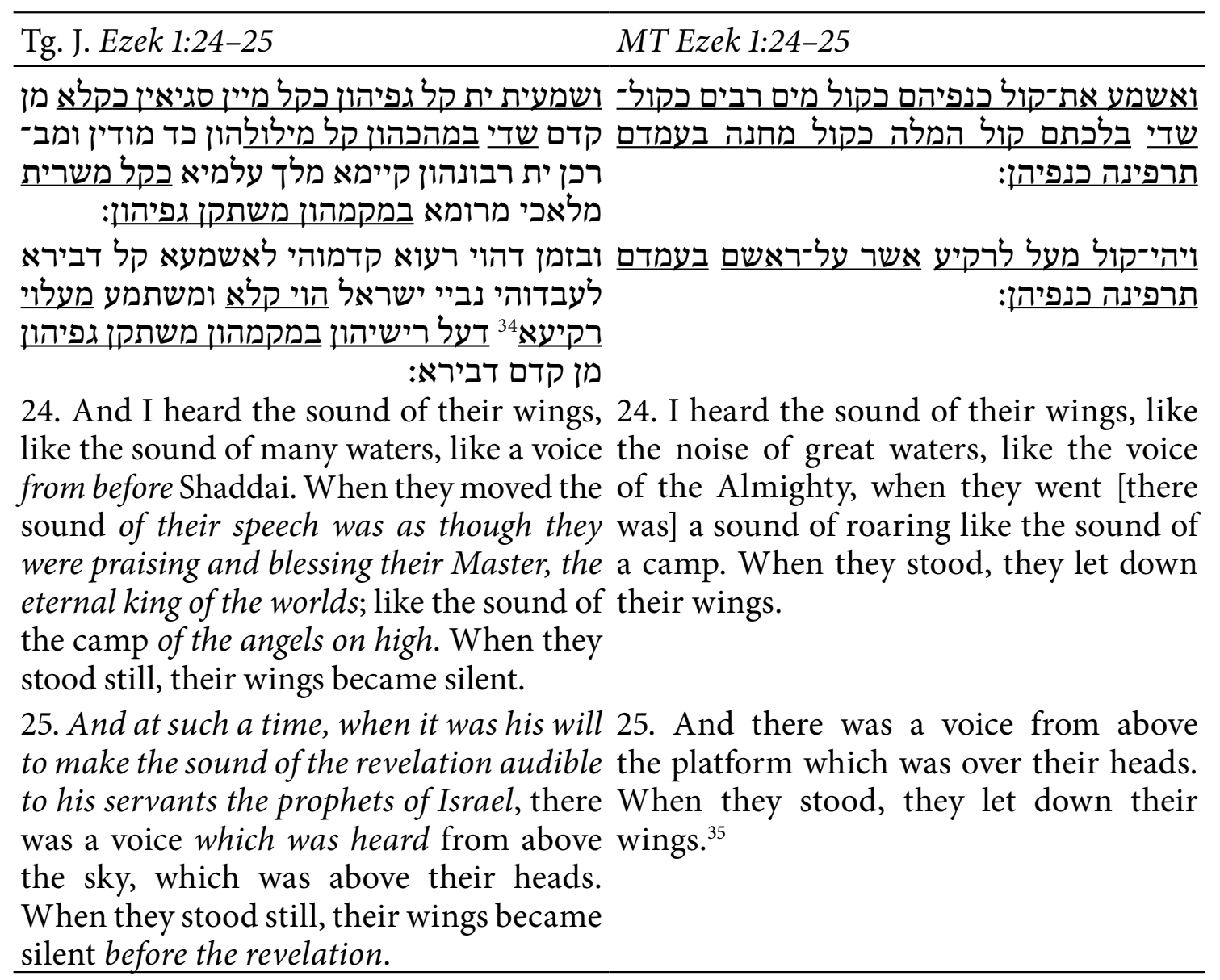

"Assimilation in Biblical Narratives," in Empirical Models for Biblical Criticism (ed. J.H. Tigay; Philadelphia: University of Pennsylvania Press, 1985), 176-96.

34 The printed editions (First and Second Rabbinic Bibles and Antwerp Polyglot) include מבין: מational plus, derived from 10:2,6-7 and added by means of Wiederaufnahme כרוביא מתחות רקיעא, "between the cherubim beneath the sky."

35 The whole verse is absent in LXX, Peshittta, and nine Hebrew mss. Verse 25a is a corrupted dittography from v. 26a, and v. 25b a dittography from v. 24b. 
Verses 24-25 contain an intricate set of related expansions, three in each verse. The first is a routine, almost stereotyped, expansion in Targum Jonathan, the new material being incorporated by splitting the constituents of the construct phrase: כקול שדא מן קדם שדי >, "like the voice of Shaddai", "like a voice before Shaddai." The second expansion in v. 24 was accompanied by a particular construal of the Hebrew noun המלה. The phrase קול המלה (חמלה, "a sound

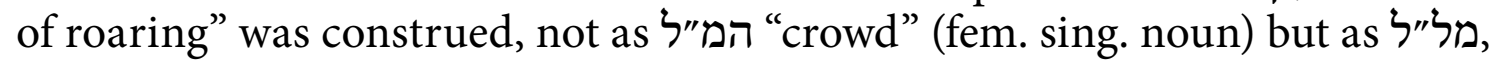
"word/speech." (def. art + fem. sing. noun). In Aramaic, the noun was given a suffixed pronoun, as an equivalent to the article, which was dropped, and the phrase was rendered, קל מילולהון, "sound of their speech." The expansion has

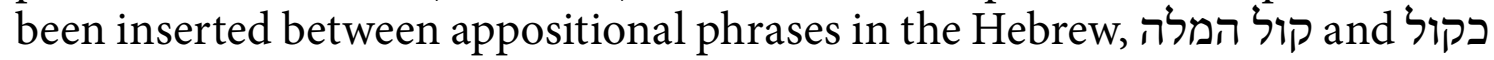
מחנה "sound of roaring" and "sound of a camp." The content of the sound is explicated in the expansion: כד מודין ומברכן ית רבונהון קיימא מלך עלמיא "as though they were praising and blessing their Master, the eternal king of the worlds." Thus, in Targum Jonathan the hayyôt do not just make a cacophonous noise. They make music, and that music is produced by the flapping of their wings (cf. Songs of the Sabbath Sacrifice - 4Q405 20 ii 7-14). This expansion serves two purposes. It fills a gap in the text, explaining what the content of the sound or speech might be, and it coordinates the verse with common knowledge about the duties of angels, namely that their first and most fundamental task is to extoll God in his heavenly temple. ${ }^{36}$

The third and final expansion in v. 24 explains the second phrase in the appositional construction, כקול מחנה, "like the sound of a camp." This camp is construed as משרית מלאכי מרומא, "the camp of the angels on high." It is extremely unusual, in Targum Jonathan, for the scribes to disclose any information about angels or angelic orders. Targum Jonathan Ezek 1 is almost unique in this respect. Here though, the scribe responsible for the expansion has not offered new information independently. Angelic camps are referenced in two other targumic texts: Ps.J. Gen 32:3 and Tg. J. 1 Kgs 19:11-12.

When Jacob saw them he said, "These are not the camps of Esau that are coming to meet me, nor are they the camps of Laban pursuing me again. They are the camps of the holy angels (משרויין דמלאכייא קדישין) who have been sent from before YHWH." $(\text { Ps. J. Gen 32:3) })^{37}$

36 See, for example, e.g., Isa 6:1-4; Tg. Neof. Gen. 32:27; Tg. J. Ezek 3:12-13, 43:2; Tg. Job 3:10; Tg. Psa. 29:1; 69:35; 96:1; 97:6; 148:1; the Songs of Sabbath Sacrifice; Apoc. Ab. 18; 3 Enoch 30-31; Hekhalot Rabbati, especially, the Qedusha Hymns (\$ 94-106) and Hymns of Praise ( $\$ 152-97) ;$ Ma'aseh Merkabah $₫ 549,590,593 ;$ Merkabah Rabbah $₫ 664-70,676,682$. See also Rev. 14.1-3; 19.6 .

37 A similar reading is found in $\mathrm{Tg}$. Neof. Gen 32:3, which may reflect the exegetical development of this notion. That is, Jacob refers to his pursuers as possibly being "messengers from Laban" (מלאכין מן דלבן) or "camps of messengers of Esau" (משרין). (משרין דמלאכין דעשו). The line "camps of angels" (משרין דמלאכין) may have been so construed as a parallel to the foregoing expressions, rather than intending to introduce the idea of angelic orders or groups. If so, Targum Neofiti may reflect the oldest reading of Gen. 32:3 in this vein and the genesis of the tradition of angelic camps. 
And YHWH appeared, and before him was the camp of the wind angels (משרית מלאכי (רוחא), breaking mountains and shattering rocks in the presence of YHWH, but the Shekinah of YHWH was not in the camp of the wind-angels (משרית מלאכי רוחא). And after the camp of the wind-angels (משרית מלאכי רוחא) was the camp of the earthquake-angels (משרית מלאכי זיעא), but the Shekinah of YHWH was not in the camp of the earthquake angels (משרית מלאכי זיעא). And after the camp of the earthquake angels (משרית מלאכי זיעא) was camp of the fire angel (משכית מלית מלאכי אישתא), but the Shekinah of YHWH was not in the camp of the fire angels (משתאה מלית מלאכי אישתי (משתית). And after the camp of fire (משרית אישתא) was a voice praising softly. (Tg. J. 1 Kgs 19:11-12)

Though 1Kgs 19:11-12 is the only text within Targum Jonathan to address types of angels and angelic camps (excepting Ezek 1:24), the tradition of angelic camps appears, on occasion, in the Second Temple literature (e.g., Songs of Sabbath Sacrifice, song 12 - 4Q405 20 ii 13) ${ }^{38}$ and midrashim as well (e.g., Gen. Rab. 74,17; b. Tanh. Wa-Yishlah $3[1,163])$. The allusion to angelic camps in $T g$. J. Ezek 1:24 coordinates the chapter with the angelology apparent in these sources, fitting the chapter into a wider world of contemporary Jewish thought. The expansion also insures that the "sound" in Ezek 1:24 is not identified with earthly voices but heavenly ones. ${ }^{39}$

Ezekiel 1:25, in the Hebrew text, opens abruptly with ויהי־קול מעל לרקיע, "and there was a sound/voice from above the platform." Targum Jonathan opens, instead, with a large expansion, a complex temporal modifier, which

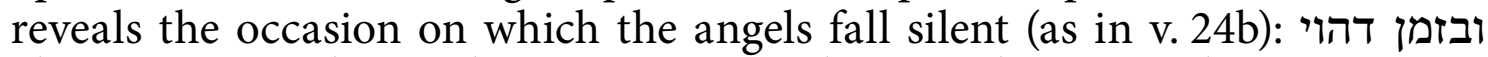
רעוא קדמוהי לאשמעא קל דבירא לעבדוהי נביי ישראל הוי קלא ומשתמע מעלוי רקיעא, "And at such a time, when it was his will to make the sound of the revelation audible to his servants the prophets of Israel, there was a voice which was heard from above the sky." The expansion reveals two things not addressed in the Targum's Vorlage. The hayyôt fall silent when God wishes his prophets to hear his revelatory word. The "voice above the sky" is the source of the דבירא, the "revelatory word," for all prophets. It is, presumably, this voice that Ezekiel hears whenever he receives an oracle. The scribe, with this one gloss, filled two gaps in the Hebrew text and created a logical connection between v. 24b ("and when they stood, they let down their wings") and 25a ("and there was a voice from above the platform").

The second expansion in v. 25, ומשתמע, "which was heard," appears superfluous. Perhaps it serves to underline that the revelatory voice was not drowned out or obscured by the hayyôt. The third expansion states explicitly what was implicit in Tg. J. vv. 24b-25a, namely that the hayyôt are still מן קדם דבירא,

38 4Q405 frg. 20 ii 13. E. Eshel, et al., Qumran Cave 4, IV: Poetical and Liturgical Texts, Part 1 (DJD XI; Oxford: Clarendon Press, 1998), 345, 347, 355.

39 There is one additional difference between Targum Jonathan of v. 24 and its Vorlage. In the MT, when the creatures stop moving they "relax their wings" (תרפינה כנפיהן). In Targum Jonathan, this is rendered "their wings became silent" (משתקן גפיהון). This reflects a difference between Hebrew and Aramaic in the semantics of the cognate. שתת משת means "let down, relax" in Hebrew, but "be silent" in Aramaic. It is impossible to tell if this difference is intentional or not. 
"before the revelation." The repetition of דבירא is a clear attempt to underline the importance of this element.

\section{B. The Nature of Targumic Exegesis in Targum Jonathan Ezek 1}

The first and most fundamental decision made by the scribes responsible for Targum Jonathan was to present their interpretation as a new version of Ezekiel rather than a commentary. They eschewed the classical commentary form found in the $p^{e}$ sharim and midrashim (lemma + comment) in favor of an interpretive form that shadowed the linguistic shape, genre, and point of view of their Vorlage. In this respect, the Targumim are akin to the (so-called) rewritten scriptures. ${ }^{40}$ This choice shaped and limited the scribes' options. Their interpretation had to be recognizable as a version of Ezekiel, limiting the mechanical techniques that were available to them, and yet it had to be distinct from the biblical book, separating between source text and target text. By mirroring the order of linguistic elements in their source text, they produced a work that was transparently a representation of the biblical book of Ezekiel. By rewriting the source text in a new language, expanding and rewording at many points, they produced a text that could not be identified as the biblical book of Ezekiel. Even more, expansion and rewording allowed the scribes to select which elements of the text they would interpret, whether individual words or larger text-segments. This is the nature of Targumic exegesis. It is pervasive in the sense that every element of the Vorlage is represented ${ }^{41}$ It is selective in that not every element receives interpretation. ${ }^{42}$

\section{Textual Cues in Targum Jonathan's Vorlage}

Certain features of their Hebrew Vorlage cued Targum Jonathan's scribes to attempt something more than an unadorned mirror of its lexemes and syntax. In the six cases examined here, there are only a few types of literary features that prompted acts of scribal rewording or expansion. These include, in order of frequency: unexplained or unclear items, repetitions, and unspecified referents. Hebrew describes the hayyôt as having hands and feet, but the purpose of neither is revealed. Similarly, the content of their speech (קול) is not explained. In cases like these, the scribes reworded or expanded upon the He-

40 Compare M. Bernstein, "4Q252: From Re-Written Bible to Biblical Commentary," JJS 45 (1994): 1-27.

41 The scribes responsible for Targum Jonathan only omit an element from their Vorlage on rare occasions. One such case (omission of an equivalent for להם) can be observed in Example 2.

42 See, especially, A. Samely, "Is Targumic Aramaic Rabbinic Hebrew? A Reflection on Midrashic and Targumic Rewording of Scripture," JJS 45 (1994): 92-100; idem, "The Targums within a New Description of Jewish Text Structures in Antiquity," AS 9 (2011): 5-38. 
brew, supplying, so to speak, the key to its linguistic code. Repetitions in Hebrew sparked some of the longest expansions, as the scribes strove to represent the Hebrew in such a way that the underlying (assumed) differences between cases of apparent repetition were clearly exposed. Finally, in one case, the referent of a character - the "man dressed in linen" (10:2, 6-7)-was unclear. This character was introduced into $1: 8$ by the targumic scribes, but, because his identify was not clear, he was introduced, by his proper designation, as one of the seraphim. All these features of the Hebrew vision arrested the attention of the targumic scribes and motivated them to undertake acts of rewording and expansion.

\section{Exegetical Choices}

The exegetical choices witnessed in Tg. J. Ezek 1 manifest varying degrees of fidelity to and flexibility with the Hebrew. This variability has been described in different ways. ${ }^{43}$ My own reading of Targum Jonathan Ezekiel, illustrated by the six examples cited here, suggests a particular conceptualization of the scribes' activities. In the case of Targum Jonathan Ezekiel, the scribes showed remarkable fidelity to the syntactic structure of their Hebrew exemplar. The scribes replicated the series of syntactic slots represented in their Vorlage. Each slot was represented in the Aramaic version, by a syntagm congruent with that of the Hebrew original: construct noun by construct noun, imperfect verb by imperfect verb, and so on. ${ }^{44}$ Certain variations in morphology do occur, particularly in number or gender, ${ }^{45}$ but the slot is always filled by an aligned Aramaic syntagm. Expansions might be included between syntactically disjunctive elements, like separate clauses, or between syntactically bound elements, like the nouns of a construct phrase or the verbs that make up a complex predicate. Nonetheless, when the expansionist elements are removed from the Aramaic version, the remaining series of graphemes closely mirrors the original in its number of elements, order of elements, and the syntactic function of elements. ${ }^{46}$

43 Prominent examples include: P.S. Alexander, "Jewish Aramaic Translations of Hebrew Scriptures," in Mikra: Text, Translation, Reading, and Interpretation of the Hebrew Bible in Ancient Judaism and Early Christianity (ed. M.J. Mulder; CRINT 2/1; Assen/Maastricht: Van Gorcum, 1990), 217-53; A. Houtman and H. Sysling, Alternative Targum Traditions: The Use of Variant Readings for the Study in Origin and History of Targum Jonathan (SAIS 9; Leiden and Boston: Brill, 2009), 7-32, esp. 16-25; W. Smelik, "Translation and Commentary in One: The Interplay of Plusses and Substitutions in the Targum of the Prophets," JSJ 29 (1998): 245-60.

44 See, importantly, n. 33 above.

45 These morphological variations occur due to certain hermeneutical commitments that will be discussed momentarily under "Hermeneutical Assumptions."

46 This, as we have seen (Example 2), does not extend to verse divisions. Fidelity to Hebrew verse divisions appears to be a lower order of obligation to the targumic scribes. In this case, also, it should be noted that the syntax of the Hebrew could be properly understood in more than one way. 
This fidelity to syntax does not extend to semantics. Here, the scribes permitted themselves greater choice. In terms of individual lexemes, in most cases, the scribes provided an Aramaic cognate to the Hebrew original, but this is not always the case. Hebrew words are, sometimes, represented in Aramaic with non-cognate equivalents. In our examples, equivalents are sometimes selected that have a semantic field that overlaps with the Hebrew original but is not cognate (e.g., הסרפ > ףכ). In other cases, words with similar but not

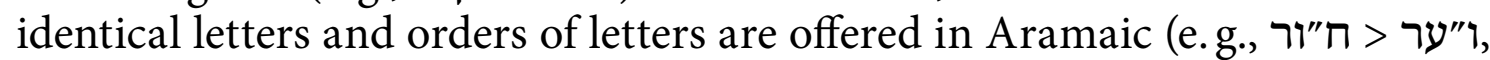
(ל"למ > ל"מה ,ל"גס > ל"גע). This is the art of rewording, and it is the most local instantiation of the scribes' exegetical efforts.

In our six examples, most of the expansions in Targum Jonathan represent an attempt to make explicit what was believed to be implicit in the Hebrew text. This too, is a species of semantic representation. That is, the targumic scribes detected an extra-linguistic component to the meaning of the Hebrew text. Something was suggested but not explicated. In these cases, the targumic scribes have offered a linguistic expression of the extra-linguistic freight. They have expanded the story, adding words that express the unexpressed, that make the implicit explicit. This is, I believe, an effort by the scribes to clarify what they believe is already present, extra-linguistically, in their Hebrew Vorlage. For this reason, I refer to these as expansions and not additions.

Regarding these expansions, the scribes tended not to create them from whole cloth. Rather, they tended to borrow locutions from other scriptural texts. This represents something more than an attempt to render their expansion in "biblical" language. In each case, the reuse signals that the scribes identified some essential connection between the source and target texts. Some of the source texts, Ezek 10 and Isa 6 for example, have obvious connections to the target text. Others are less obvious, like Zech 1 and 6. In each case, however, the expansion coordinated the target with the source text, bringing them into alignment with one another in various ways. Thus, the horizon of the present text, Ezek 1, was, in the targumic scribes' view expansive indeed. What it might mean is only evident from the vantage of its wider literary context. In the case of the examples addressed here, the relevant context is at least as wide as the prophetic corpus. In this way too, then, the scribes took pains to render fully the perceived semasiological content of their Vorlage.

In two cases, the content of the expansion was derived from another Targum (Exa. 5 and 6). Here the scribes chose not to leave to chance the role that Ezek 1 should and would play in the development of rabbinic angelology. Its role was confined and defined by the expansion. Similar acts of coordination between Ezekiel and wider themes and debates in rabbinic thought are common in Targum Jonathan Ezekiel, as we might expect in one of the "official" Targumim. In these cases, the Aramaic version is accurate in the sense that it strives to represent a correct interpretation.

Thus, in the case of Targum Jonathan, the object of the Targum is to provide an accurate and complete representation of the syntax and semantics of 
the Hebrew original. It is accurate in that it mirrors Hebrew syntax. It also mirrors Hebrew word-choice, so long as the Aramaic cognates are explicative of the scribes' understanding of the text. If they are not, accuracy dictates alternative choices. Some words and phrases in the Hebrew are freighted with unexpressed meaning. "Hands," for example, imply labor of some sort, which is unexpressed in the original. In these cases, expansions are required, to make explicit the implicit, to make the rendering complete. Accuracy and completeness are the ideals of scribal exegesis in Targum Jonathan. These ideals, though, are themselves the products of certain hermeneutical assumptions about the nature of their Vorlage.

\section{Hermeneutical Assumptions}

Exegetical choices, like those represented in the examples in this essay, provide the evidence from which we can infer the hermeneutical assumptions under which they were made. In the case of the scribes responsible for Targum Jonathan, their hermeneutical assumptions are co-extensive with their assumptions about the nature of scripture. Two such assumptions are particularly evident from our six examples. First, there is a clear commitment to the notion that scripture is meaningful. That is, the elements that make up a scriptural text are full of meaning. The substance of a scriptural locution cannot be reduced to the semantic cargo of its individual words. Locutions may be freighted with implications, with referential deixis, and, in the case of משרית מלאכי מרומא for example, with extra-biblical concepts and notions. They are full of meaning in another sense as well, namely, every part of scripture bears meaning. Nothing in the Hebrew text is superfluous. Even apparent redundancies are not bereft of a semantic contribution. The input of a particular locution to the text-segment's meaning or significance may not be readily apparent, but it is of the nature of Targum to make it apparent.

Second, the scribes who gave us Targum Jonathan believed that scripture is cohesive and coherent. ${ }^{47}$ This assumption impacts their renderings at every turn. Small adjustments to the grammar of a text are made to reveal or enhance its internal cohesion (e.g., רגל > רגלין). Links to other text-segments are forged to reveal and reinforce the coherence of a book or of scripture as a whole. The rewording "man dressed in linen" (Heb האיש לבש הבדים) > "seraphim" (Aram סרפיא) in Tg. J. Ezek 1:8, for example, not only clarified the relationship of the man to the hayyot t, it also clarified the relationship of the hayyôt to the seraphim. In so doing, it provided not only conceptual clarity for the readers of scripture, it brought Ezek 1 and 10 into harmony with one another and brought both into harmony with Isa 6. Scripture is a complex web of

47 Cohesion refers to "the ways in which the components of the surface text, i.e., the actual words we hear or see, are mutually connected within a sequence." Coherence refers to "the configuration of concepts and relations that underlie the surface text." R. de Beaugrande and W. Dressler, Introduction to Text Linguistics (London: Longman, 1981), 3-4. 
graphic, ideational, and propositional communication. Such complexity need not result in incoherence. Scripture's web, in the eyes of the targumic scribes, is perfect in symmetry and design. It is perfectly cohesive and perfectly coherent. The art of targumic rendering is in making that perfection apparent to every eye. 